\title{
Editorial: Special issue on learning design research: Mapping the terrain
}

\author{
Eva Dobozy \\ Curtin University \\ Leanne Cameron \\ Southern Cross University
}

Learning design as a field of educational research and practice is gaining traction internationally. Not only is learning design now acknowledged as a complex and integrated process, demanding specialised knowledge and skills, it is a field of technology enhanced learning and teaching that is forward looking and globally focused. This special issue is unable to provide a unified position of what learning design is or resolve the debate, but it is able to contribute to a better understanding of the complexity of this field of educational research and practice. It also showcases some of the cutting-edge work currently conducted internationally in learning design research and development.

\section{Introduction}

Learning design is undoubtedly a popular, but still fuzzy concept and an emerging field of educational research and practice. The field is maturing, with the articulation of theoretical and methodological frameworks, the availability of a wide range of tools, and the build-up of a canon of literature (Mor, Craft, \& Maina, 2015). Learning design is now acknowledged as a complex and integrated process, which includes stages of planning, designing, orchestrating and running of sequenced teaching and learning activities. Dobozy (2013) has defined learning design as "a way of making explicit epistemological and technological integration attempts by the designer of a particular learning sequence or series of learning sequences” (p. 68). The pedagogical sequencing of online learning activities that are interactive and engaging and clearly aligned with contemporary learning theories, can be complex and especially demanding for academics new to learning design thinking and practice (Alexander, Dalziel, Krajka, \& Dobozy, 2013; Cameron, 2017; Dalziel, 2013; Goodyear, 2005; Laurillard, 2012).

Learning design is, to the frustration of many researchers working in this field, often confused with instructional design, which has a distinct and much longer history that can be traced back to the beginning of the 20th century. The field of learning design is relatively new and emerged at the beginning of the 21st century. Its purpose is to provide support and guidance to educators teaching in online learning environments. More precisely, the field of learning design aims to help educators understand how to develop, use and reuse contemporary pedagogical designs, many of which are built on social constructivist learning theory (Dobozy, 2017). Given the increasing interest in learning design among researchers, practitioners and policy makers, this special issue of AJET provides an interesting cross-section of research offering a glimpse of the future directions of learning design research and development.

This special issue is unable to provide a unified position of what learning design is or resolve the debate, but it is able to contribute to a better understanding of the complexity of this field of educational research and practice. This special issue contains a set of papers authored by international educational researchers grappling to advance the field. It is able to contribute to the advancement of the field, addressing issues of significance, such as the need for a design support framework, artefact design framework, design provisions for massive open online course (MOOC) designs, building teacher expertise, design patterns and visual representations of learning designs, learning design support tools and the intersection of learning design and learning analytics. In this regard, it has much to offer to higher education teachers. 


\section{Higher education teacher knowledge}

An increasing number of tertiary providers are requiring their teaching staff to design and deliver personalised, mobile, technologically enhanced learning environments to their students (Salmon \& Wright, 2014). It is now often expected that to be successful academics, HETs would possess a comprehensive understanding in all the following areas:

- Subject content knowledge: Subject content or discipline knowledge that is to be passed on to students is the one area in which most HETs report they feel confident (Cameron, 2017).

- Pedagogical knowledge: Pedagogical knowledge is what an educator understands about teaching and learning. It involves their determining how to organise the learning environment, so they can offer systematic assistance'in such a way that students can learn effectively (Laurillard, 2012).

- Design knowledge: Design knowledge is knowledge of the principles of design, the design process and how to apply design thinking that is epistemologically and ontologically consistent (Dobozy, 2012).

- Technology enhanced learning knowledge: Designing learning with technology makes aspects of teaching visible that were previously taken for granted in a face-to-face learning environment (Beetham \& Sharpe, 2007). Much of the early learning design research was focused on how technology could assist the learning design process (Dalziel, 2013).

The field of learning design continues to develop models and tools that are able to combine knowledge domains, visualisation and evaluation practices that assist HETs as designers of effective learning processes.

\section{Capturing the status quo of the learning design field}

Nearly a decade ago, Cameron (2009, p. 20) wrote that "the field of Learning Design holds the promise of providing educators with a framework that will enable them to design high quality, effective and innovative learning”. Despite the increasingly extensive research and voluminous literature available, the learning design academic community is still seeking conceptual unity when it comes to defining the nature, parts and processes of learning design research and practice. One of the key challenges the field will need to overcome to advance its research and development impact, is the multiplicity of conceptualisations and definitions concurrently in use (Cameron, 2009; Dobozy, 2013; Dobozy \& Vlachopoulos, 2017a, 2017b; Goodyear \& Dimitriadis, 2013).

A serious attempt to capture succinctly the theory, history and purpose of the field of learning design was undertaken in 2012. A group of those working in the field was brought together so that they might arrive at a consensus for the field of learning design. This event produced an unprecedented alignment of focus and documentation for the learning design work of those present, which was outlined in the Larnaca declaration (Dalziel et al., 2016). The authors make a clear distinction between learning design theory and practice. They provided a visual representation of their current understanding of learning design as a pedagogical meta-model with three distinct but interconnected components (Dalziel et al., 2016). These are a learning design conceptual map (LD-CM), a learning design framework (LD-F), followed by learning design practice (LD-P). New interpretations and approaches continue to emerge and the field remains a fragmented (Persico \& Pozzi, 2015).

The issues the Larnaca group (Dalziel et al., 2016) determined were the major concerns of the field of learning design are:

- How can teachers become more effective in their preparation and facilitation of teaching and learning activities?

- How can educators be exposed to new teaching ideas that take them beyond their traditional approaches?

- How can technology assist educators without undermining them?

- How can learners be better prepared for the world that awaits them? (adapted from Lloyd \& Bahr, 2016). 


\section{Inside this special issue}

The articles that have been selected for this special issue are quite diverse but represent the broad scope that is typical of the research currently being undertaken in the field of learning design. The first two papers look at how educators in the higher education sector design for learning.

In the first paper, "Identifying the characteristics of support Australian university teachers use in their design work: Implications for the learning design field”, Agostinho, Lockyer, and Bennett investigate the supports that HETs use when they design for learning. The authors note that the participants personalised the supports to suit their context, and the type and mix of support they used changed over time, depending on their career stage and circumstances. The nature of the supports was inherently social, comprising a network of colleagues, drawing connections with other people's teaching and learning ideas.

In the second paper, "4FAD: A framework for mapping the evolution of artefacts in the learning design process”, Muñoz-Cristóbal et al. also looked at how learning is designed but took an activity theory-inspired approach by studying the artefacts designers of learning generate and use. The authors introduce the 4FAD framework, which maps the artefacts throughout the learning design life cycle. This approach signifies a move away from the traditional learning design tool development that focuses on the final product, to one that evaluates all those artefacts generated and used throughout the different stages of the learning design process.

The next two papers feature MOOCs. In "A framework for self-determination in massive open online courses: Design for autonomy, competence, and relatedness”, Martin, Kelly, and Terry consider how engagement might be nurtured within a MOOC - a learning environment where participant attrition is normally extremely high. The framework was developed from self-determination theory, which draws a relationship between intrinsic motivation and the need for autonomy, competence, and relatedness. The paper outlines design principles for improving engagement, motivation, and retention for open online learning.

In "Evaluation to support learning design: Lessons learned in a teacher training MOOC”, Garreta-Domingo, Hernandez-Leo, and Sloep use a MOOC for delivering learning design knowledge to a broad range of educators. The educators were introduced to heuristics and heuristic evaluation as a means of assisting them to design an ICT-based learning activity. Unsurprisingly, the study found that this resulted in a steep learning curve for the educators.

The final three papers of this special issue focus on unique way to bridge the gap between learning design theory and practice. Throughout "Finding creative processes in learning design patterns", Philip explores what can be learned about teaching creatively and fostering student creativity. By providing a pattern that foregrounds the creative processes, she was able to make these educators' approaches to teaching creatively more explicit. This shed some light on where the creative processes reside in the learning process and adds another piece to the puzzle of how educators' learning designs can be articulated so they might be shared.

"CuVIS: An interactive tool for instructors to create effective customised learning designs with visualisations", authored by Banerjee and Murthy, describes the design and implementation of a learning design tool that assists educators design constructively aligned, effective learning designs while they teach with visualisations. Using the CuVIS design guidelines, educators were able to transition from a teaching-centric learning environment to a more learning-centric one.

In "Informing learning design through analytics: Applying network graph analysis", Ifenthaler, Gibson, and Dobozy apply graph theory analysis to inform learning design and assessment. Through the integration of analytics data into the design of learning environments, they demonstrate how learning designers can evaluate and measure the impact of interventions and feedback in near real time. By integrating analytics data with the theoretical underpinnings of learning design, the field may gather renewed impetus and provide further insights into the complex world of designing for learning. 


\section{Looking ahead}

As interest in learning design grows, so does the international community of learning design researchers and practitioners. We argue that it is vital that common theoretical foundations can be established to move the field forward. As a specialised field of technology enhanced learning and teaching, it is imperative that researchers and practitioners are able to arrive at a set of agreeable learning design theories (LDT) that will support learning design research (LDR) and learning design practice (LDP) and adaptive reuse of sharable learning design models (LDM).

\section{Acknowledgements}

We are indebted to the reviewers of the numerous manuscripts submitted to this special issue and to the AJET editorial team and copyeditors for their support in bringing this special issue to fruition.

\section{References}

Alexander, C., Dalziel, J., Krajka, J., \& Dobozy, E. (2013). (Eds.). Learning design. Nicosia, Cyprus: University of Nicosia Press.

Beetham, H., \& Sharpe R. (2007). Rethinking pedagogy for a digital age: Designing and delivering e-learning. London: Routledge.

Cameron, L. (2009, December 10). How learning design can illuminate teaching practice. Paper presented at the Future of Learning Design Conference, University of Wollongong, Wollongong, Australia. Retrieved from http://ro.uow.edu.au/fld/09/Program/3

Cameron, L. (2017). How learning designs, teaching methods and activities differ by discipline in Australian universities. Journal of Learning Design, 10(2), 69-84. https://dx.doi.org/10.5204/jld.v10i2.289

Dalziel, J. (2013). Implementing learning design: A decade of lessons learned. In In H. Carter, M. Gosper, \& J. Hedberg (Eds.), Electric Dreams. Proceedings ascilite 2013 Sydney (pp. 210-220). Australasian Society for Computers in Learning in Tertiary Education. Retrieved from http://www.ascilite.org/conferences/sydney13/program/papers/Dalziel,\%20James.pdf

Dalziel, J., Conole, G., Wills, S., Walker, S., Bennett, S., Dobozy, E., ... Bower, M. (2016). The Larnaca declaration on learning design. Journal of Interactive Media Education. 2016(1). https://doi.org/10.5334/jime.407

Dobozy, E. (2012). Typologies of learning design and the introduction of a 'LD-type 2' case example. In P. Ullmo \& T. Koskinen (Eds.), eLearning Papers - Special edition 2012: Opening learning horizons (pp. 42-53). Barcelona: eLearning Europa. Retrieved from https://www.openeducationeuropa.eu/sites/default/files/news/eLP_Special_Edition2012.pdf

Dobozy, E. (2013). Learning design research: Advancing pedagogies in the digital age. Educational Media International, 50(1), 63-76. https://doi.org/10.1080/09523987.2013.777181

Dobozy, E. (2017). The pre-designed lesson: Teaching with transdisciplinary pedagogical templates (TPTs). Technology, Knowledge and Learning, 22(2), 1-8. https://doi.org/10.1007/s10758-017-9304-5

Dobozy, E., \& Vlachopoulos, P. (2017a, October 27). Learning design - Not just another buzzword! [Blog post]. TELal: Technology Enhanced Learning. Retrieved from http://blog.ascilite.org/learning-design-notjust-another-buzzword-part-1/

Dobozy, E., \& Vlachopoulos, P. (2017b, November 3). Learning design - Not just another buzzword! [Blog post]. TELal: Technology Enhanced Learning. Retrieved from http://blog.ascilite.org/learning-design-notjust-another-buzzword-part-2/

Goodyear, P. (2005). Educational design and networked learning: Patterns, pattern language and design practice. Australian Journal of Educational Technology, 21(1), 82-101. https://doi.org/10.14742/ajet.1344

Goodyear, P., \& Dimitriadis, Y. (2013). In medias res: Reframing design for learning. Research in Learning Technology, 21(SUPPL.1), 1-13. https://dx.doi.org/10.3402/rlt.v21i0.19909

Laurillard, D. (2012). Teaching as a design science: Building pedagogical patterns for learning and teaching. New York, NY: Routledge. 
Lloyd, M., \& Bahr, N. (2016). What matters in higher education: A meta-analysis of a decade of learning design. Journal of Learning Design, 9(2), 1-13. https://dx.doi.org/10.5204/jld.v9i2.280

Mor, Y., Craft, B., \& Maina, M. (2015). Learning design: Definitions, current issues and grand challenges. In M. Maina, B. Craft, \& Y. Mor (Eds.), The art \& science of learning design (pp. ix-xxvi). Rotterdam: Sense Publishers.

Persico, D., \& Pozzi, F. (2015). Informing learning design with learning analytics to improve teacher inquiry. British Journal of Educational Technology, 46(2), 230-248. https://doi.org/10.1111/bjet.12207

Salmon, G., \& Wright, P. (2014). Transforming future teaching through 'Carpe Diem' learning design. Education Sciences, 4, 52-63. https://doi.org/10.3390/educsci4010052

Corresponding author: Eva Dobozy, eva.dobozy@curtin.edu.au

Australasian Journal of Educational Technology @ 2018.

Please cite as: Dobozy, E., \& Cameron, L. (2018). Editorial. Australasian Journal of Educational Technology, 34(2), i-v. https://doi.org/10.14742/ajet.4390 